\title{
Scanning agroforestry-based solutions for climate change mitigation and adaptation in Europe
}

Mónica Hernández-Morcillo ${ }^{1}$, Paul Burgess ${ }^{2}$, Jaconette Mirck ${ }^{3}$, Anastasia Pantera ${ }^{4}$, Tobias

Plieninger ${ }^{5}$

Corresponding author: Mónica Hernández-Morcillo, m.hernandezmorcillo@gmail.com

${ }^{1}$ Department of Geosciences and Natural Resource Management, University of Copenhagen, Frederiksberg C, Denmark

${ }^{2}$ School of Water, Energy and Environment, Cranfield University, Cranfield, Bedfordshire, MK43 OAL, UK

${ }^{3}$ Department of Soil Protection and Recultivation, Brandenburg University of Technology Cottbus Senftenberg, Germany

${ }^{4}$ Department of Forestry and Natural Environment Management, Technological Educational Institute (TEI) Stereas Elladas, 36100 Lamia, Greece

${ }^{5}$ Chair of Social-Ecological Interactions in Agricultural Systems, University of Kassel and University of Göttingen, Germany

\section{Highlights}

- Agroforestry can make a substantial contribution to the European Climate Change Strategy.

- The potential of agroforestry will only unfold when the barriers to implementation are addressed through the most efficient solutions.

- Training programmes for agroforestry managers and development of safe economic routes are key solutions to promote sustainable agroforestry systems.

- Improved soil organic carbon pools and implementation of multifunctional hedgerows are the solutions holding the greatest mitigation and adaptation potential respectively.

\begin{abstract}
Agroforestry, the integration of trees and shrubs with livestock and/or crops, can make a substantial contribution to mitigating and enabling adaptation to climate change. However, its full potential will only be achieved if the challenges to agroforestry implementation are identified and the most efficient and sustainable solutions are made widely known. Therefore, the aim of this paper is to explore these challenges and to determine the most suitable set of solutions for each challenge that combines local effectiveness with European scale relevance. We performed a two-step "solution scanning" exercise. First, the main challenges to sustainable agroforestry in Europe were identified through 42 participatory workshops with 665 local stakeholders. The solutions to each challenge were scanned and classified into either direct solutions (28) to address climate change or indirect solutions (32) that improve the sustainability of agroforestry. In a second step, the direct solutions were prioritized through expert consultation in terms of their potential benefits for mitigation and adaptation. The most commonly reported barriers were a lack of knowledge and reliable financial support to which the most widely suggested indirect solutions were agroforestry training programmes and the development of safe economic routes. The direct solutions considered as
\end{abstract}


holding the greatest mitigation and adaptation potential were the adoption of practices capable to increase soil organic carbon pools and the implementation of multifunctional hedgerow and windbreaks respectively. We believe that our solution scanning approach could contribute to the implementation of the European climate strategy in general and to the Common Agricultural Policy in particular by pointing to concrete climate beneficial actions.

Keywords: climate change strategy, Common Agricultural Policy, Europe, nature-based solutions

\section{Acknowledgements}

We especially thank the participants of the AGFORWARD workshops and the online survey for their time and valuable contributions. This research received support through the AGFORWARD project (Grant Agreement $N^{\circ}$ 613520) from the European Commission (7th Framework Program).

\section{Introduction}

Europe is warming faster than many other parts of the world. Over the past decade the European land temperature has increased by $0.3^{\circ} \mathrm{C}$ more compared to the global average rise since the preindustrial era (IPCC, 2013). Although all EU Member States are affected by climate change, the impacts will vary across sectors and countries.

Agriculture is particularly dependent on the climate, therefore farming activities will need to adapt, particularly in the southern and south-eastern regions of the EU where the negative effects will be greatest (EC, 2015a). At the same time, agriculture also releases greenhouse gases (GHG) to the atmosphere. Around 10\% of Europe's GHG emissions are derived from agriculture (EEA, 2012). Consequently, European agriculture will need to both adapt to climate change to enhance resilience and mitigate climate change by reducing its emissions.

Agroforestry has been identified as one of the most promising measures capable to integrate both targets (Martineau et al., 2016). It can be considered a nature-based solution to climate change (NBS) as it is supported by nature and can simultaneously provide multiple environmental, social and economic benefits (Cohen-Shacham et al., 2016; EC, 2015b).

\subsection{Agroforestry and climate change}

Agroforestry can play a significant role in mitigating the atmospheric accumulation of GHGs while helping farmers adapt to climate change (Sharrow and Ismail, 2004; Lal, 2004; Verchot, 2007; Mosquera-Losada et al., 2008; Aertsens et al., 2013; Mbow et al., 2014; Upson et al., 2016). In particular it offers important opportunities of creating synergies between both adaptation and mitigation actions (Verchot et al., 2007; Shoeneberger et al., 2012).

Two key beneficial attributes of agroforestry systems in terms of mitigation are direct C storage in trees and soils and the potential to offset immediate GHG emissions (Dixon, 1995). Agroforestry systems are able to store more $C$ than conventional arable systems (Baah-Acheamfour et al. 2014) and have a global technical mitigation potential of 1.1-2.2 Pg C sequestered within terrestrial ecosystems over the next 50 years (IPCC, 2007). In particular, agroforestry practices can deliberately enhance the soil organic carbon $(\mathrm{SOC})$ pool, the only terrestrial pool storing $\mathrm{C}$ for millennia (Lorenz and Lal, 2014). Aertsens et al. (2013) estimated a theoretical annual sequestration from agroforestry 
of $1.56 \mathrm{Pg} \mathrm{C}$ in the EU27, if it was introduced on 90 million ha of arable land and 50 million ha of pasture land. However, the proposed system would lead to decreases in agricultural production. For example, Upson (2014) calculated that a poplar system at $10 \mathrm{~m} \times 6.4 \mathrm{~m}$ spacing in the UK would sequester 2.7-2.9 t C/(ha year) in trees, but arable crop production was no longer profitable for 12 years after tree planting. A long-term agroforestry system that integrates trees on crop or pasture land and allows agriculture to remain productive over the long-term is likely to sequester $\mathrm{C}$ at a lower level. Although the values cited by Aertsens et al. (2013) may be excessively high, they indicate that there is strong potential for agroforestry practices to be expanded in Europe (Mosquera-Losada et al., 2016), contributing positively to the EU climate change strategy (EC, 2013).

Agroforestry can also reduce the negative impacts of climate change and enhance resilience of European farmers, for example by reducing the effects of extreme weather events. In Spain, an experiment combining short-cycle cereals and late sprouting walnuts demonstrated that partial shade could offer protection from the from the more frequently occurring spring heat waves that are damaging cereal crops in Mediterranean countries (Arenas-Corraliza et al., 2016). Additionally, agroforestry systems could provide greater stability through more diversified enterprises with different sources of income and products distribution over time providing a buffer against yield fluctuations caused by unstable climate or extreme weather events. For example, silvopastoral systems allow farmers to establish a tree crop (which can for example provide timber and fuelwood) whilst maintaining forage and livestock production (Méndez et al., 2010; Cubbage et al., 2012). A summary of agroforestry benefits for climate change is presented in Table 1.

Table 1. Agroforestry benefits for mitigation and adaptation to climate change (adapted from Schoeneberger et al., 2012)

\begin{tabular}{lll}
\hline $\begin{array}{l}\text { Climate change } \\
\text { activity }\end{array}$ & $\begin{array}{l}\text { Major climate change } \\
\text { functions }\end{array}$ & $\begin{array}{l}\text { Agroforestry functions that support climate } \\
\text { change mitigation and adaptation }\end{array}$ \\
\hline Mitigation & Sequester carbon & $\begin{array}{l}\text { Accumulate } \mathrm{C} \text { in woody biomass } \\
\text { Accumulate } \mathrm{C} \text { in soil }\end{array}$ \\
\cline { 2 - 3 } & Reduce GHG emissions & $\begin{array}{l}\text { Reduce fossil fuel consumption in equipment } \\
\text { Reduce } \mathrm{CO}_{2} \text { emissions from farmstead structures } \\
\text { Reduce } \mathrm{N}_{2} \mathrm{O} \text { emissions by greater nutrient uptake } \\
\text { and reduced } \mathrm{N} \text { fertilizers }\end{array}$ \\
& Reduce $\mathrm{CH}_{4}$ by enhancing forage quality \\
\hline Adaptation & Enhance resilience & $\begin{array}{l}\text { Maintain quality and quantity of products } \\
\text { Increase habitat diversity } \\
\text { Increase structural and functional diversity }\end{array}$ \\
& Foster diversified production opportunities \\
\hline & Reduce impacts of extreme weather events \\
& Reduce stress in flora and fauna \\
\cline { 2 - 3 } & Reduce threats & Provide travel corridors for fauna migration \\
\hline
\end{tabular}

Besides, agroforestry can provide diverse ecosystem services (Tsonkova et al., 2014; Fagerholm et al., 2016) such as enhanced nutrient cycling, reduced risks of soil erosion and flooding (Rivest et al.,2013; Carroll et al., 2006), increased biodiversity (Torralba et al., 2016), and integrated pest 
management and improved resistance to diseases (Bianchi et al., 2006; Beer et al.,1998). Due to their environmental and socio-economic benefits, agroforestry systems represent an important value for society in general and for the agricultural sector in particular (Aertsens et al., 2013).

\subsection{Agroforestry in Europe}

The European Union has defined agroforestry as "land use systems in which trees are grown in combination with agriculture on the same land" (EU, 2013a). It has been estimated to cover 15.4 million ha of land in the European Union (EU 27) (den Herder et al., 2017). When adding grazed shrublands (2.7 million ha) and homegardens (1.8 million ha), the total cover of agroforestry amounts to ca. 20 million ha (Mosquera-Losada et al., 2016). About 90\% of this area is linked to silvopastoral practices, a combination of forestry and grazing of domesticated animals. Agroforestry is promoted through the EU Common Agricultural Policy (CAP) Pillar I as one of the choices of the ecological focus area (EFA) greening options (EU, 2013b). However, this recognition is restricted only to the establishment of new agroforestry systems (not to the maintenance of existing ones). Additionally, agroforestry is supported by the CAP Pillar II through the European Rural Development Council Regulations 1698/2005 (art. 44) and 1305/2013 (art.22, art.23), in recognition of its role in reducing $\mathrm{C}$ emissions and promoting $\mathrm{C}$ sequestration, which would help to fulfil the requirements of the Paris Agreement.

\subsection{Realising the climate benefits of agroforestry}

Despite its high potential, agroforestry has not yet been adopted on a large scale as a mitigation or adaptation mechanism in most countries of the EU, and its uptake is growing slowly due to several socio-economic and technical challenges (Martineau et al., 2016; Garcia de Jalon et al., 2017). In particular, the high practical experience needed to deal with complex management and the lack of reliable advice and financial support are strong barriers for farmers to implementing agroforestry systems (Martineau et al., 2016). To enable agroforestry in Europe to contribute to climate change, these barriers need to be identified in more detail and overcome. Hence, the aim of this paper is to explore these challenges, and to determine the most suitable set of solutions that combines local effectiveness with European scale relevance. In particular, we prioritize a set of potential solutions for mitigation and adaptation to climate change by consulting European agroforestry experts.

\section{Methods}

To facilitate a comprehensive list of agroforestry-based solutions, we performed a "solution scanning" exercise. Solution scanning is a structured, step-wise methodology to identify a long list of actions, interventions, or approaches that respond to a broad challenge (Sutherland, 2014). Such a list can be useful in a broader decision-making process to produce practical or policy interventions, but also for setting research agendas (Dicks et al., 2017; Sutherland et al. 2014). Firstly, a goal is defined, which is derived from a normative societal concern about change or loss (Pullin et al., 2013). Secondly, experts are asked to list what interventions they are aware of from their own experiences that can leverage the system toward the stated goal. Thirdly, the interventions are collated and redistributed to the experts, where they are assessed, cross-checked, and prioritized according to a given criteria (Fazey et al., 2006; Plieninger et al., 2017).

We applied a solution scanning exercise in two steps. In the first phase, we identified the challenges threatening the sustainability of agroforestry in Europe and scanned the corresponding solutions 
through participatory workshops. The solutions obtained were classified into direct and indirect solutions to climate change. In a second phase, the direct solutions were then prioritized through expert consultation.

\subsection{First step: scanning challenges and solutions for sustainable agroforestry systems}

Agroforestry systems need to be sustainably managed in order to produce long-term benefits (Schoeneberger et al., 2012). Due to this precondition, we built on previous studies assessing farmer attitudes towards agroforestry in Europe (e.g. Liagre et al., 2005; Graves et al., 2009, 2017; García de Jalón et al., 2017) but took these further by identifying the barriers impeding their sustainable implementation and scanning the corresponding solutions. We did this by analysing the reports from 42 participatory agroforestry workshops held with local stakeholders across four agroforestry systems in 12 European countries within the AGFORWARD project in 2014 (www.agforward.eu). We focused on the different categories of European agroforestry systems identified by Burgess et al. (2015): (i) agroforestry systems of high nature and cultural value which are widely recognized for their biodiversity and heritage values (e.g. traditional systems such as the dehesa, montado, and other forms of wood pasture and hedgerows) (10 workshops), (ii) agroforestry systems with high value trees (e.g. grazed or intercropped orchards or olive groves)(10 workshops), (iii) agroforestry systems where the crop component is of main interest (e.g. windbreaks in arable systems)(11 workshops), and (iv) agroforestry systems centering on livestock production (e.g. fodder trees for ruminants)(11 workshops).

The workshops had a common design but allowed flexible formats to adapt to different audiences. During the first part, the stakeholders identified the positive and negative perceptions of agroforestry whose outcomes were analysed (García de Jalón et al., 2017). In the second part of the workshops, the participants discussed the main challenges affecting their agroforestry systems and proposed solutions.

For the purpose of this study, we focused on the outcomes of the open discussions. From each workshop, the qualitative information was extracted and tabulated codifying the whole challenges and solutions proposed according to the agroforestry system and country. Then, the itemised challenges were processed, eliminating redundant and unclear formulations. The remaining challenges were sorted into three major categories of challenges: 1) socio-economic viability, 2) supportive governance, and 3) adequate management. The frequency in which each challenge was reported was calculated, and those challenges with higher values were filtered as subcategories. Later, the distribution of the challenges across countries and agroforestry systems was analysed.

Next, the proposed solutions were listed and scanned in a similar fashion as the challenges. They were then classified as direct and indirect solutions. Direct solutions are those agroforestry management practices that have the potential to mitigate and/or to adapt to climate change impacts. Indirect solutions are those that enable sustainable agroforestry systems in a broader sense, for instance appropriate governance structures, viable socio-economic factors or adequate practices. They provide the foundation for effective implementation of direct solutions. To ensure that the solutions are relevant to specific challenges but still applicable at European scale, we filtered those that were proposed by at least two stakeholders groups from two countries and/or agroforestry systems. Lastly, the resulting solutions were matched with the challenge subcategory that they were most suitable to address, and a summary list was generated. 


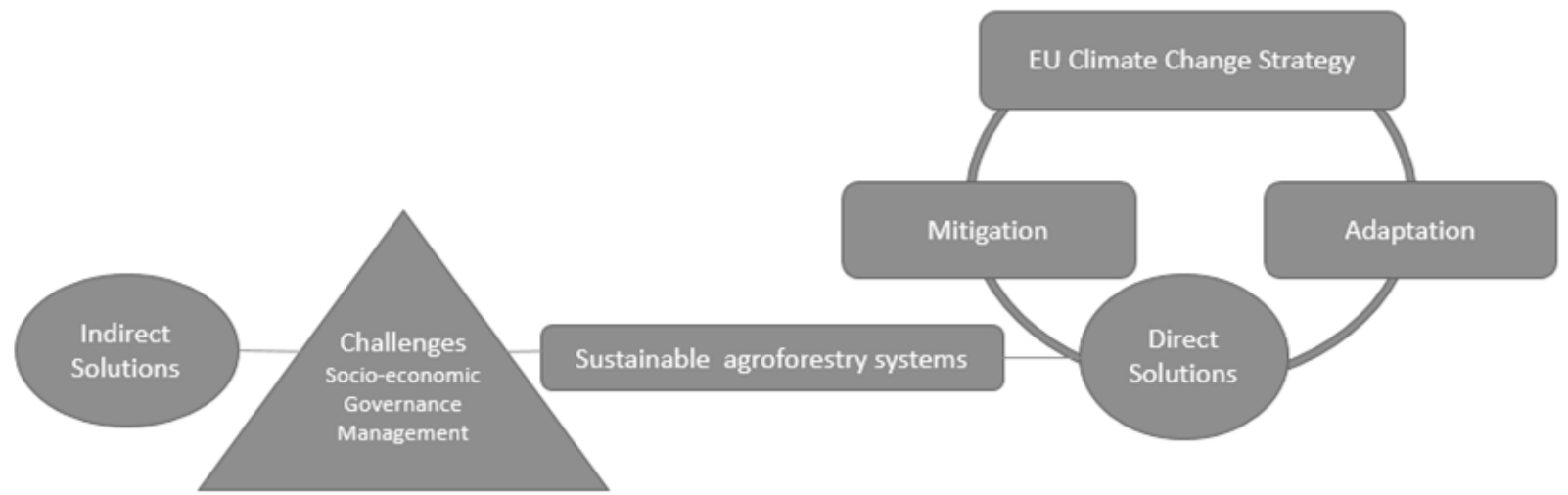

Figure 1. Methodological conceptual framework

\subsection{Second-step: prioritizing solutions for climate change}

The direct solutions were prioritized through an expert consultation process. We used Google Forms which facilitate online surveys that can be responded individually while allowing different respondents to answer simultaneously. In July 2017, the questionnaire was pretested by the research team. After having refined its configuration, a total of 165 experts working directly with agroforestry systems management in Europe at local, national or European scale were invited to the self-administered online survey. Members of the AGFORWARD project, the European Agroforestry Federation (EURAF), and the European Innovation Partnership for Agriculture (EIP-AGRI) focus group on agroforestry were invited to rank the solutions according to their potential contribution to climate change.

The survey was divided into four parts. Firstly, the consultation process and the criteria needed to accomplish the prioritization exercise were explained. Secondly, the participants were asked to provide information on their role and on their type of knowledge about agroforestry systems, using the classification of expertise by Collins and Evans (2007). Thirdly, the respondents were asked to rate the solutions according to their potential benefits for climate change mitigation and adaptation along a Likert scale (1: very low, 2: low, 3: medium, 4: high or 5: very high). The experts were invited to propose additional agroforestry-based solutions. A final ranking of the top-ten prioritized solutions for mitigation and adaptation was created.

\subsection{Data analysis}

All statistical analyses were performed using MATLAB (MathWorks, Natick, MA, USA). A p-value $<0.05$ was considered significant for all statistical tests. In the first step, Student's $t$-tests were applied to the final number of challenges $(n=220)$ and solutions $(n=182)$ classified in the major categories: socio-economic viability, supportive governance and adequate management. We tested for differences of challenges and solutions across agroforestry systems types (4) and European countries (12). Finally, we explored potential correlations between the countries' centroid coordinates (CIA World Factbook, 2011), challenge types, and solution types. The results derived from the expert consultation were analyzed to assess significant differences between adaptation and mitigation solutions by performing two-tailed Student's $t$-tests across role types (scientists / policy-maker / practitioner / NGOs / others) and knowledge types (contributory / interactional / 
primary / popular / contextual). Finally, we compared the level of agreement between all role types and knowledge types using pairwise Pearson's correlation analyses.

\section{Results}

\subsection{Analysis of the challenges to agroforestry systems}

A total of 665 local stakeholders participated in the AGFORWARD workshops. They identified 220 challenges. After processing, 155 challenges remained from which 41 related to problems of socioeconomic viability, 39 to a lack of supportive governance, and 76 to inadequate management of the agroforestry systems.

The distribution of reported problems across European countries was uneven. Problems related to adequate management were the most reported ones and were significantly more frequent than socio-economic $(p=0.0007)$ and governance challenges $(p=0.0014)$. For example, those related to management were the only challenges described in Romania and Sweden (Figure 2). Workshop participants in Hungary and the Netherlands identified the lack of supportive governance in $40 \%$ of their total challenges while in United Kingdom, there was no reference to any governance issue. Problems related to the socio-economic viability of agroforestry systems were reported with similar frequency (20\%-32\%) in all countries except for Romania and Sweden (Figure 2a). We found no clear geographical patterns across south-north/west-east European countries.

Across agroforestry system types, socio-economic related challenges were not significantly different from governance and management challenges. However, significant differences persisted between the last two $(p=0.04)$. Managers of intercropped (68\%) and livestock systems $(63 \%)$ reported more often problems related to complexity and inadequacy of their management practices. On the other hand, managers of agroforestry systems of high nature value and arable farms reported higher challenges related to inadequate governance and socio-economic viability (55\%) (Figure 2b).

\subsection{Solution scanning}

A total of 263 solutions were proposed across all workshops. After pre-processing, 53 vague solutions were eliminated and 46 were merged with similar solutions proposed at workshop level. At the end, 164 remained. The amount of reported solutions to improve management of agroforestry systems was significantly higher than those proposed to adequate governance $(p=0.026)$ and socioeconomic viability $(p=0.005)$. After filtering those solutions identified by stakeholders groups in two or more countries and agroforestry systems, we obtained 33 indirect and 28 direct solutions to climate change. Being aware that they may address simultaneously several challenges, we matched all solutions to the problem they were most suitable to address (Table 2).

The highest number of indirect solutions were proposed to improve the markets conditions for agroforestry products (5) and to overcome the lack of knowledge and expert support to agroforestry managers (5) by for example developing effective payments for ecosystem services schemes or implementing exchange and training programmes for farmers. 


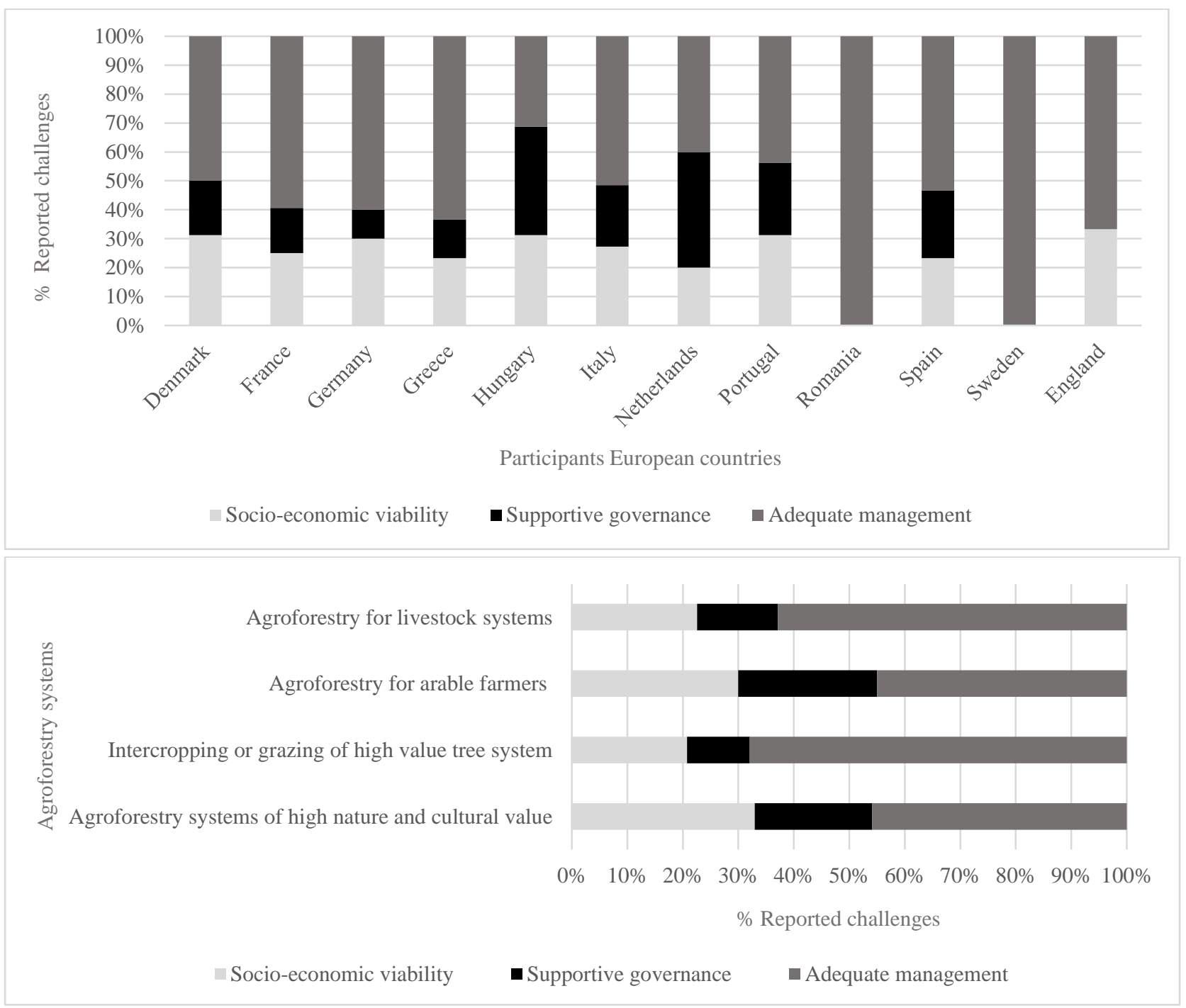

Figure 2. Distribution of reported challenges a) across European countries, b) across agroforestry systems 
Table 2. Indirect solutions to the challenges of agroforestry systems in Europe

\begin{tabular}{|c|c|c|}
\hline Challenge & Subcategory & Solutions \\
\hline \multirow{4}{*}{$\begin{array}{l}\text { Socio- } \\
\text { economic } \\
\text { viability }\end{array}$} & $\begin{array}{l}\text { High management } \\
\text { costs }\end{array}$ & Promotion of cooperative management \\
\hline & Low profitability & $\begin{array}{l}\text { Development of "safe economic routes" for profitable agroforestry } \\
\text { systems. } \\
\text { Increased diversification of marketable products. } \\
\text { Implementation of practices that provide annual and short-term } \\
\text { income. }\end{array}$ \\
\hline & $\begin{array}{l}\text { Lack of social } \\
\text { awareness }\end{array}$ & $\begin{array}{l}\text { Promotion of the social value of agroforestry systems for local } \\
\text { communities. } \\
\text { Creation of farmers' networks and skills pools. } \\
\text { Showcasing local innovations as they change farmers' visions of } \\
\text { agroforestry. }\end{array}$ \\
\hline & Lack of markets & $\begin{array}{l}\text { Development of local markets for secondary and by-products. } \\
\text { Improvement of trademark and branding of products. } \\
\text { Coordination of marketing and information through organization of } \\
\text { farmers. } \\
\text { Research business opportunities: effective marketing concepts, } \\
\text { identification of arguments and consumers perceptions for premium } \\
\text { prices. } \\
\text { Development of payment schemes for ecosystem services. }\end{array}$ \\
\hline \multirow[t]{3}{*}{$\begin{array}{l}\text { Supportive } \\
\text { governance }\end{array}$} & $\begin{array}{l}\text { Deficient financial } \\
\text { support }\end{array}$ & $\begin{array}{l}\text { Facilitation of access to public subsidies. } \\
\text { Provision of higher, longer and more flexible payments. } \\
\text { Creation of incentive payments for good performance. }\end{array}$ \\
\hline & $\begin{array}{l}\text { Lack of } \\
\text { administrative } \\
\text { support }\end{array}$ & $\begin{array}{l}\text { Communication of agroforestry benefits to policy-makers. } \\
\text { Improved government employees' assistance in the field. }\end{array}$ \\
\hline & $\begin{array}{l}\text { Lack of adapted } \\
\text { policies }\end{array}$ & $\begin{array}{l}\text { Improved land ownership schemes. } \\
\text { Clarification and flexibility of regulations (e.g. matching permits for tree } \\
\text { and crop management). } \\
\text { Improved eligibility criteria of agroforestry systems in the CAP Pillar I. } \\
\text { Legal recognition of diverse agroforestry systems. }\end{array}$ \\
\hline \multirow[t]{4}{*}{$\begin{array}{l}\text { Adequate } \\
\text { management }\end{array}$} & $\begin{array}{l}\text { Complexity of the } \\
\text { management }\end{array}$ & $\begin{array}{l}\text { Description of best practices, and collection of data for bench marking. } \\
\text { Establishment of pilot farms to test and disseminate innovations. } \\
\text { Development of technical guidelines on establishment of agroforestry } \\
\text { systems. }\end{array}$ \\
\hline & $\begin{array}{l}\text { Lack of knowledge } \\
\text { and expert support }\end{array}$ & $\begin{array}{l}\text { Creation of exchange and training programs for agroforestry managers. } \\
\text { Development of a web portal to share knowledge and experiences. } \\
\text { Establishment of plantations trials to test tree species, range of } \\
\text { intercrops, crop rotations, fodder grasses and shrubs to determine } \\
\text { optimal interactions. } \\
\text { Research of natural practices to manage pests, diseases and wildlife. } \\
\text { Modeling ideal spacing to maximize yields and/or livestock capacity. }\end{array}$ \\
\hline & $\begin{array}{l}\text { Technological } \\
\text { constrains }\end{array}$ & Research of new technologies to develop suitable machinery. \\
\hline & $\begin{array}{l}\text { Ensuring } \\
\text { sustainability }\end{array}$ & $\begin{array}{l}\text { Protection of trees (e.g. use of nursery shrubs, artificial thorny } \\
\text { protectors, mycorrhizal plants, prevention of oak death, use repellents). } \\
\text { Use of intercrops rich in legumes } \\
\text { Creation of multipurpose hedgerows }\end{array}$ \\
\hline
\end{tabular}




\subsection{Prioritization of agroforestry-based direct solutions to climate change}

The 28 direct solutions, 14 to mitigation and 14 to adaptation, were ranked through an online survey by European experts. The complete list of direct solutions can be found in the supplementary material.

Fifty respondents from 15 European countries participated, to with France (28\%) and Germany (12\%) being the most represented. From the participants, 39 identified themselves as scientists (78\%), 2 as policy-makers (4\%) and 9 as practitioners or facilitators (18\%). The response rate $(30 \%)$ was similar to that of related studies (e.g. Rosenberg et al. 2010; Rudd 2011; Braunisch et al. 2012; Hernandez-Morcillo 2017), where return rates obtained were within the range of what can be expected from a web survey (Kaplowitz et al. 2004). Most of the participants identified their type of knowledge as contributory (52\%) and interactional expertise (28\%).

Overall the t-test revealed significantly higher potential benefits $(p=0.0002)$ assigned to agroforestry-based solutions to adaptation ( $3.77 \pm 0.15 \mathrm{SEM}$ ) than to mitigation ( $3.57 \pm 0.12 \mathrm{SEM}$ ). This effect was also consistent for the two sub-groups, e.g. scientists $(p=0.0018)$ and non-scientists $(p=0.0473)$, and for three knowledge types, e.g. contributory $(p=0.0137)$, interactional $(p=0.0021)$ and primary $(p=0.0354)$. Significant agreement between scientists $(n=39)$ and non-scientists $(n=11)$ was found overall $\left(r=0.814, p=1.38 \times 10^{-7}\right.$ ) (Figure 4) and also for both solution types, mitigation $\left(r=0.806, p=4.98 \times 10^{-4}\right)$ and adaptation $\left(r=0.885, p=2.61 \times 10^{-5}\right)$. Furthermore, a significant overall agreement was found within the following knowledge types: contributory vs. interactional $(r=0.758$, $\left.p=1.98 \times 10^{-6}\right)$, contributory vs. primary $\left(r=0.653, p=1.98 \times 10^{-4}\right)$, and interactional vs. primary $\left(r=0.674, p=8.34 \times 10^{-5}\right)$.

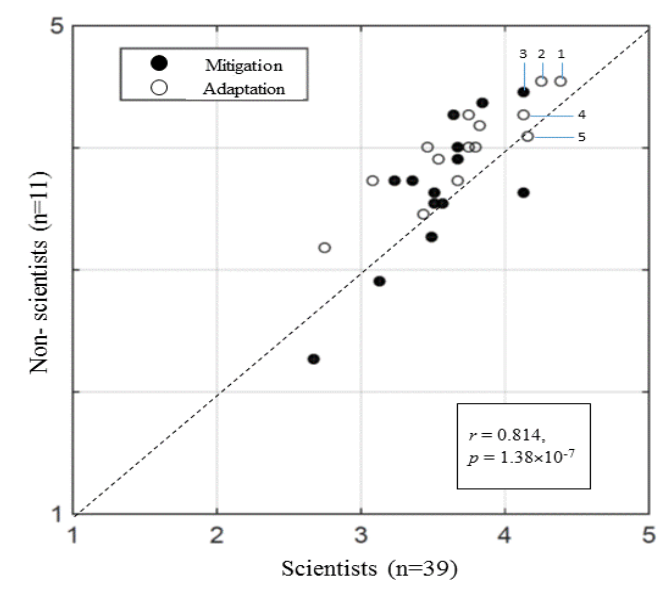

Figure 3. Correlation between scientists' and non-scientists' prioritization of agroforestry based solutions for mitigation and adaptation. The top-five solutions are marked with the corresponding number 

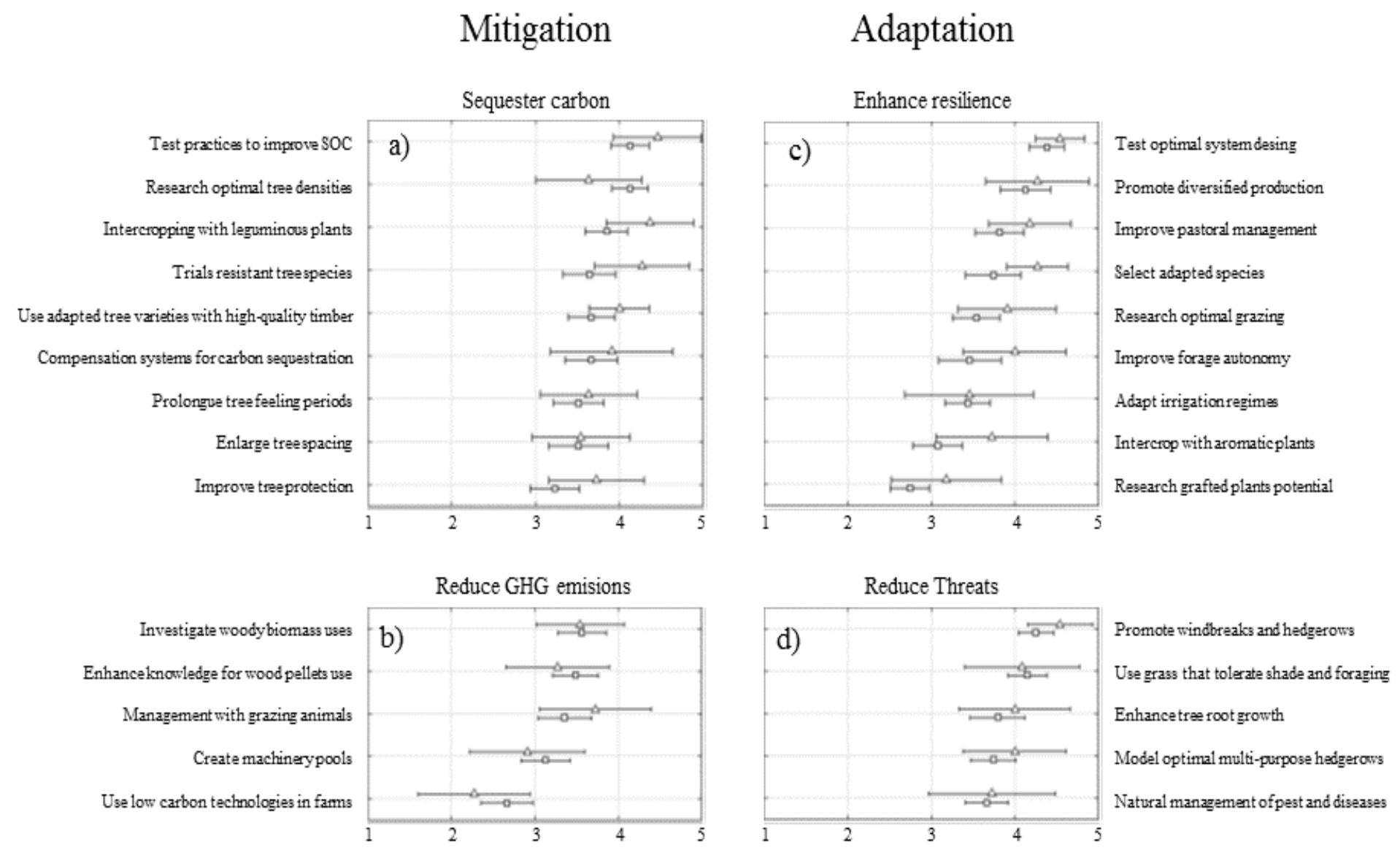

Figure 4. Outcome of agroforestry-based solutions for climate change scoring from scientists (squares) and non-scientists (triangles) with error bars reflecting the standard errors of the mean (SEM). a) Mitigation solutions to sequester carbon b) Mitigation solutions to reduce GHG emissions c) Adaptation solutions to enhance farmers' resilience d) Adaptation solutions to reduce threats

Generally, no significant difference was found between solutions prioritized by scientists and those by non-scientists. However, agroforestry-based solutions to adaptation received higher values from non-scientists than from scientists (Figure 4). As for agroforestry-based solutions to mitigation, the highest prioritized action to sequester $\mathrm{C}$ emissions (Figure 4a) was to test agroforestry practices that improve SOC (4.20 \pm 0.21 ). For reducing GHG (Figure $4 \mathrm{~b}$ ), the use of low carbon technologies in farms to manage agroforestry systems was considered the least important solution $(2.58 \pm 0.29)$ while investigating the use of woody biomass was most highly ranked ( $3.56 \pm 0.26)$ by scientists. Regarding solutions for adaptation through enhanced resilience (Figure 4c), the most highly ranked action $(4.42 \pm 0.18)$ with high agreement among all experts was to test optimal agroforestry designs adapted to different climatic conditions. Regarding solutions to reduce climate change threats (Figure 4d), promoting the use of windbreaks and hedgerows was assessed by scientists and nonscientists as the solution with highest potential $(4.32 \pm 0.19)$.

In Table 3, we present the top-ten solutions for mitigation and adaptation. Increasing C sequestration by improving $\mathrm{SOC}$ and using adapted tree varieties to diverse climate conditions were among the top-five solutions to mitigate climate change. For adaptation, the solutions considered 
with the greatest beneficial potential were mostly referring to enhancing farmers' resilience. Special interest was dedicated to modeling and testing optimal designs of agroforestry systems adapted to different climatic conditions, enabling diversified products opportunities while maintaining their quantity and quality. Respondents provided fifteen additional solutions which can be found in the supplementary material.

Table 3. Top-ten agroforestry-based direct solutions to mitigation and adaptation to climate change in Europe (*solutions with potential for both mitigation and adaptation)

\begin{tabular}{|c|c|c|c|c|}
\hline $\begin{array}{l}\text { Climate } \\
\text { Change activity }\end{array}$ & $\begin{array}{l}\text { Total } \\
\text { Rank }\end{array}$ & Solution & $\begin{array}{l}\text { Climate change } \\
\text { function }\end{array}$ & Agroforestry function \\
\hline \multirow[t]{5}{*}{ Mitigation } & 1 & $\begin{array}{l}\text { Adoption of management } \\
\text { practices that improve SOC }\end{array}$ & $\begin{array}{l}\text { Reduce GHG } \\
\text { emissions } \\
\text { Sequester C }\end{array}$ & $\begin{array}{l}\text { Reduce } \mathrm{N} \text { fertilizers and } \\
\text { accumulate } \mathrm{C} \text { soil }\end{array}$ \\
\hline & 2 & $\begin{array}{l}\text { Development of models to } \\
\text { maximize wood production } \\
\text { and } C \text { sequestration potential }\end{array}$ & Sequester $\mathrm{C}$ & $\begin{array}{l}\text { Accumulate } \mathrm{C} \text { in woody } \\
\text { biomass }\end{array}$ \\
\hline & 3 & $\begin{array}{l}\text { Intercropping with leguminous } \\
\text { plants }\end{array}$ & $\begin{array}{l}\text { Reduce GHG } \\
\text { emissions }\end{array}$ & Reduce $\mathrm{N}$ fertilizers \\
\hline & 4 & $\begin{array}{l}\text { Innovative use of tree species } \\
\text { that resist livestock and } \\
\text { diseases under different } \\
\text { climatic conditions }{ }^{*}\end{array}$ & Sequester $\mathrm{C}$ & $\begin{array}{l}\text { Accumulate } \mathrm{C} \text { in woody } \\
\text { biomass }\end{array}$ \\
\hline & 5 & $\begin{array}{l}\text { Introduction of adapted tree } \\
\text { varieties appropriate for } \\
\text { production of high-quality } \\
\text { timber }\end{array}$ & Sequester $\mathrm{C}$ & $\begin{array}{l}\text { Accumulate } \mathrm{C} \text { in woody } \\
\text { biomass }\end{array}$ \\
\hline \multirow[t]{5}{*}{ Adaptation } & 1 & $\begin{array}{l}\text { Testing of the optimal range of } \\
\text { intercrops and crop-rotation } \\
\text { to maximize yields, livestock } \\
\text { capacity under different } \\
\text { climatic conditions }\end{array}$ & $\begin{array}{l}\text { Enhance } \\
\text { resilience }\end{array}$ & $\begin{array}{l}\text { Maintain quality and } \\
\text { quantity of production and } \\
\text { foster diversified production } \\
\text { opportunities }\end{array}$ \\
\hline & 2 & $\begin{array}{l}\text { Development and } \\
\text { maintenance of } \\
\text { multifunctional windbreaks } \\
\text { and hedgerows with trees and } \\
\text { shrubs }\end{array}$ & Reduce threat & $\begin{array}{l}\text { Reduce impacts of extreme } \\
\text { weather events and increase } \\
\text { diversity }\end{array}$ \\
\hline & 3 & $\begin{array}{l}\text { Development of models to } \\
\text { integrate diverse marketable } \\
\text { products }\end{array}$ & $\begin{array}{l}\text { Enhance } \\
\text { resilience }\end{array}$ & $\begin{array}{l}\text { Foster diversified production } \\
\text { opportunities }\end{array}$ \\
\hline & 4 & $\begin{array}{l}\text { Introduction of grass mixes } \\
\text { that can tolerate shade and } \\
\text { foraging in low-competitive } \\
\text { combinations }\end{array}$ & $\begin{array}{l}\text { Enhance } \\
\text { resilience }\end{array}$ & $\begin{array}{l}\text { Maintain quality and } \\
\text { quantity of production }\end{array}$ \\
\hline & 5 & $\begin{array}{l}\text { Improvement of pastoral } \\
\text { management to facilitate } \\
\text { precision grazing under } \\
\text { different climatic conditions }{ }^{*}\end{array}$ & $\begin{array}{l}\text { Enhance } \\
\text { resilience }\end{array}$ & $\begin{array}{l}\text { Maintain quality and } \\
\text { quantity of production }\end{array}$ \\
\hline
\end{tabular}




\section{Discussion}

In this study, we make the case that agroforestry in Europe can deliver long-term climate benefits, but these are often inhibited by strong barriers. Both direct and indirect actions are needed to harness the contributions of agroforestry to climate change mitigation and adaptation. Our solution scanning exercise presented has been useful in: i) identifying the challenges to sustainable agroforestry in Europe, ii) matching solutions to each challenge which can be implemented at European level, and iii) prioritizing agroforestry-based solutions for climate change mitigation and adaptation.

\subsection{From challenges to solutions}

Although barriers vary across countries and agroforestry systems, our exercise identified a number of common issues. The majority of stakeholders considered the low profitability of agroforestry systems as one of the most important challenges to implementation (c.f. Garcia de Jalon et al., 2017). Many ecosystem services provided by agroforestry are often not compensated financially for the benefits they provide (Graves et al., 2017; Garcia de Jalon et al., 2017). The most commonly identified solution to address this issue included the development of safe economic routes, meaning the diversification with marketable products, and improvement of business opportunities through targeted marketing strategies.

In many cases, integrating trees into arable or livestock systems requires the use of new skills, techniques or equipment (Calfapietra et al., 2010), and unfamiliarity with appropriate management practices and lack of expert support can be barriers to uptake (Martineau et al., 2016). National demonstrations and education programs could help addressing these challenges (Garcia de Jalon et al., 2017). In particular, the development of guidelines, training programs and exchange opportunities among agroforestry managers were identified as suitable solutions. Besides, to showcase local innovations and disseminate the benefits among farmers and policy makers could positively transform their visions on agroforestry.

In addition to these issues, farmers have to deal as well with administrative constraints. Conflicts with the eligibility criteria from CAP direct payments and the lack of flexible subsidies were a common concern. For example in the Spanish dehesa, farmers highlighted the difficulty of retaining full eligibility of wood pastures for Pillar I CAP payments (Garcia de Jalon et al., 2017). A wider appreciation of agroforestry within the CAP and its support through long-term subsidies could help solve these issues.

\subsection{Agroforestry-based solutions to climate change}

The experts consulted showed high agreement on the prioritization of the solutions for climate change, independently of their role and knowledge type, suggesting that the ranking was robust.

The recognition of agroforestry as a mitigation strategy under the Kyoto Protocol has improved its appreciation as a C sequestration strategy (Nair et al., 2008). Four of the top five ranked agroforestry-based solutions to mitigation, targeted increasing $C$ sequestration by accumulation in soil or woody biomass. In line with published evidence, the adoption of practices capable to increasing SOC pools is considered as holding the greatest mitigation potential. For example, planting trees together with $\mathrm{N}$-fixing vegetation can increase $\mathrm{C}$ and $\mathrm{N}$ concentrations in the soil (Johnson and Curtis, 2001). Additionally, broadleaf trees with deep and extensive root systems and 
high belowground to aboveground biomass ratios may enhance the potential for $\mathrm{C}$ sequestration (Lorenz and Lal, 2014).

The use of innovative tree varieties adapted to different climatic conditions was highly ranked (total rank 4 and 5) by all experts. Use of adequate genetic material was considered a key action for adaptation and mitigation as well. A greater understanding of tree variety responses to climate change can be studied through local experiments that consider climate-related traits in measurement and design (Rehfeldt et al., 2002; Alfaro et al., 2014). For animal-pollinated crop and tree species in particular, research is also needed on the effects of climate change on their reproductive capacity (Hegland et al., 2009). Studies have further stressed the need to monitor the response of tree varieties to fires, pests and diseases since their incidence is expected to increase (Verchot et al., 2007; Syampungani et al., 2010; Schoeneberger et al., 2012).

The fact that adaptation solutions received significantly higher values than the mitigation ones could indicate that experts show higher concerns to reduce threats and enhance resilience to climate change impacts in Europe. Around $90 \%$ of the top agroforestry-based solutions to adaptation pointed to actions that alter the microclimate to maintain high and diversified production. The most preferred solution to reduce climate change threats was the development and maintenance of multifunctional hedgerow and windbreaks. Hedgerows play an important role for agricultural production as their positive impacts on field crops are diverse (Cleugh, 1998; Mayus et al., 1999). They improve crop yields, reduce soil erosion, improve water efficiency, protect livestock and conserve energy (Schoeneberger, 2012). Establishing hedgerows in agricultural landscapes has also potential for creating wildlife corridors, allowing the movement of populations (Hilty et al., 2006) to places with better climate conditions.

\section{Conclusions}

Although agroforestry is a widespread practice in the EU-27 (den Herder et al., 2017), the expansion of existing areas of agroforestry and the establishment of new agroforestry systems has remained limited (Martineau et al., 2016). This study highlights that the most common challenges for uptake are a lack of knowledge and expert support to ensure adequate management and a lack of financial support from the EU Common Agricultural Policy.

The most commonly proposed solutions to address these challenges were the development of training and expert support programmes for managers, and improved sharing of best practices on how agroforestry can support climate mitigation and adaptation actions in different regions of the EU. There is also a need to resolve the mixed-messages within the current CAP on the financial impacts of tree planting on agricultural land, so that agroforestry can fully contribute to climate mitigation and adaptation.

Given the potential of agroforestry and the ambitious climate goals of the $\mathrm{EU}$, the promotion of agroforestry is particularly pertinent in those European regions where the negative effects of climate change are greatest. Promoting agroforestry would benefit the integration of the mitigation and adaptation targets for agriculture within the overall EU climate strategy. The substantial co-benefits provided by agroforestry means that it could serve as a metaphor for the development of synergies between mitigation and adaptation policies. In that sense, agroforestry is an exemplar for the 
development of"nature-based solutions" to solve societal challenges such as climate change, a field that is strongly on the rise at current (Raymond et al., 2017).

\section{References}

Aertsens J, De Nocker L, Gobin A (2013) Valuing the carbon sequestration potential for European agriculture. Land Use Policy 31: 584-594. DOI: 10.1016/j.landusepol.2012.09.003

Alfaro RI, Fady B, Vendramin GG, Dawson IK, Fleming RA, Sáenz-Romero C, Skrøppa, T (2014) The role of forest genetic resources in responding to biotic and abiotic factors in the context of anthropogenic climate change. For Ecol Manage 333:76-87. DOI:

10.1016/i.foreco.2014.04.006

Arenas-Corraliza G, Mantino A, López-Díaz ML, Moreno G (2016) Cropping among trees to cope with climate change. In: Gosme, M. et al (eds) 3rd European Agroforestry Conference Book of Abstracts. Montpellier, France, 23-25 May 2016.

Baah-Acheamfour M, Chang S, Carlyle C, Bork E (2015) Carbon pool size and stability are affected by trees and grassland cover types within agroforestry systems of western Canada. Agric Ecosyst Environ 213:105-113. DOI:10.1016/jagee.2015.07.016

Beer J, Muschler R, Kass D, Somarriba E (1998) Shade management in coffee and cacao plantations. Agroforest Syst 38:139-164. DOI: 10.1023/A: 1005956528316

Bianchi FJJA, Booij CJH, Tscharntke T (2006) Sustainable pest regulation in agricultural landscapes: a review on landscape composition, biodiversity and natural pest control. Proc $R$ Soc $B$ 273:1715-1727. DOI: 10.1098/rspb.2006.3530

Burgess PJ, Crous-Duran J, den Herder M, Dupraz C, Fagerholm N, Freese D, Garnett K, Graves AR, Hermansen JE, Liagre F, Mirck J, Moreno G, Mosquera-Losada MR, Palma JHN, Pantera A, Plieninger T, Upson M (2015) AGFORWARD Project Periodic Report: January to December 2014. Cranfield University, AGFORWARD, Cranfield.

Calfapietra C, Ainsworth EA, Beier C, De Angelis P, Ellsworth DS, Godbold DL, Hendrey GR, Hickler T, Hoosbeek MR, Karnosky DF, King J (2010) Challenges in elevated CO2 experiments on forests. Trends Plant Sci 15:5-10. DOI:10.1016/j.tplants.2009.11.001

Carroll ZL, Bird SB, Emmett BA, Reynolds B, Sinclair F (2006) Can tree shelterbelts on agricultural land reduce flood risk?. Soil Use Manage 20: 357 - 359. DOI: 10.1111/j.1475-2743.2004.tb00381.x.

Central Inteligence Agency (CIA) World Factbook 2011. https://www.cia.gov/library/publications/the-world-factbook/fields/2011.html. Accessed 30 August 2017

Cleugh HA (1998) Effects of windbreaks on airflow, microclimates and crop yields. Agrofor Syst 41,1: 55-84. DOI: 10.1023/A:1006019805109

Cohen-Shacham E, Walters G, Janzen C, Maginnis S (2016) Nature-based solutions to address societal challenges. Gland, Switzerland. IUCN. DOI: 10.2305/IUCN.CH.2016.13.en

Collins H, Evans R (2007) Rethinking Expertise. Bibliovault OAI Repository, the University of Chicago Press. DOI: 10.7208/chicago/9780226113623.001.0001

Cubbage F, Balmelli G, Bussoni A, Noellemeyer E, Pachas AN, Fassola H, Colcombet L, Rossner B, Frey G, Dube F, Silva ML, Stevenson H, Hamilton J, Hubbard W (2012) Comparing silvopastoral systems and prospects in eight regions of the world. Agrofor Syst 86: 303-314. DOI: 10.1007/s10457-012-9482-z

den Herder M, Moreno G, Mosquera-Losada MR, Palma JHN, Sidiropoulou A, Santiago Freijanes JJ, Crous-Duran J, Paulo JA, Tomé M, Pantera A, Papanastasis VP, Kostas Mantzanas K, Pachana P, 
Papadopoulos A, Plieninger T, Burgess PJ (2017) Current extent and stratification of agroforestry in the European Union. Agric Ecosyst Environ 241:121-132. DOI:

10.1016/j.agee.2017.03.005

Dicks L, Haddaway N, Hernández-Morcillo M, Mattsson B, Randall, N, Failler P, Ferretti J, Livoreil B, Saarikoski H, Santamaria L,Rodela R, Velizarova E, Wittmer H (2017) Knowledge synthesis for environmental decisions: an evaluation of existing methods, and guidance for their selection, use and development-a report from the EKLIPSE Project

Dixon RK (1995) Agroforestry systems: sources or sinks of greenhouse gases. Agrofor Syst 31: 99116. DOI: $10.1007 / B F 00711719$

European Commission (EC) (2013) An EU Strategy on adaptation to climate change. 216 final, Brussels, 16.4.2013. Accessed 20 August 2017

European Commission (EC) (2015a) EU agriculture and climate change factsheet. https://ec.europa.eu/agriculture/sites/agriculture/files/climate-change/factsheet_en.pdf. Accessed 20 August 2017

European Commission (EC)(2015b) Towards an EU research and innovation policy agenda for naturebased solutions \& re-naturing cities. Final Report of the Horizon 2020 Expert Group on NatureBased Solutions and Re-Naturing Cities

European Environmental Agency (EEA) (2012) Climate change, impacts and vulnerability in Europe 2012. An indicator-based report, European Environment Agency. EEA Report No 12/2012. ISSN 1725-9177

European Union (EU) (2005) Regulation No 1698/2005 on support for rural development by the European Agricultural Fund for Rural Development (EAFRD). Official Journal of the European Union L 277/1

European Union (EU) (2013a) Regulation No 1307/2013 on establishing rules for direct payments to farmers under support schemes within the framework of the common agricultural policy

European Union (EU) (2013b) Regulation No 1305/2013 on support for rural development by the European Agricultural Fund for Rural Development (EAFRD) and repealing Council Regulation (EC) No 1698/2005.

Fagerholm N, Torralba M, Burgess P, Plieninger T (2016) A systematic map of ecosystem services assessments around European agroforestry. Ecol Indic 62: 47-65.

DOI:10.1016/j.ecolind.2015.11.016.

Fazey I, Fazey JA, Salisbury JG, Lindenmayer DB, Dovers S (2006) The nature and role of experiential knowledge for environmental conservation. Environ Conserv 33:1-10. DOI:10.1017/ S037689290600275

García de Jalón S, Burgess P, Graves AR, Moreno G,McAdam J, Pottier E, Novak S, Bondesan V, Mosquera-Losada MR, Crous-Duran J, Palma J, Paulo J, Oliveira T, Cirou E, Hannachi Y, Pantera A, Wartelle R, Kay S, Malignier N, Vityi A (2017) How is agroforestry perceived in Europe? An assessment of positive and negative aspects by stakeholders. Agrofor Syst. DOI:10.1007/s10457-017-0116-3

Graves AR, Burgess PJ, Liagre F, Dupraz C (2017) Farmer perception of benefits, constraints, and opportunities for silvoarable systems in Bedfordshire, England. Outlook Agric 46,1: 74-83. DOI: $10.1177 / 0030727017691173$

Graves AR, Burgess PJ, Liagre F, Pisanelli A, Paris P, Moreno G, Bellido M, Mayus M, Postma M, Schindler B, Mantzanas K, Papanastasis VP, Dupraz C (2009) Farmer perceptions of silvoarable systems in seven European countries. In: Rigueiro-Rodriguez A, McAdam J, Mosquera-Losada 
MR (eds) Agroforestry in Europe. Current Status and Future Prospects, Springer, $\mathrm{p} 45$. ISSN: 978-1-4020-8272-6

Hegland SJ, Nielsen A, Lázaro A, Bjerknes AL, Totland $\varnothing$ (2009) How does climate warming affect plant-pollinator interactions?. Ecol Lett 12, 2: 184-195. DOI: 10.1111/j.14610248.2008.01269.x

Hilty JA, Lidicker WZ, Merenlender AM (2006) Corridor Ecology: The science and practice of linking landscapes for biodiversity conservation. Island Press, Washington DC. ISBN: 1-55963-047-7

IPCC (2007) Climate change 2007: The scientific basis. Contribution of Working Group I to the Fourth Assessment Report of the Intergovernmental Panel on Climate Change. Cambridge University Press, Cambridge

IPCC (2013) Climate change 2013: the physical science basis. Contribution of Working Group I to the Fifth Assessment Report of the Intergovernmental Panel on Climate Change. Cambridge University Press, Cambridge

Johnson DW, Curtis PS (2001) Effects of forest management on soil C and N storage: meta analysis. For Ecol Manage 140, 2: 227-238. DOI: 10.1016/S0378-1127(00)00282-6

Lal R (2004) Soil carbon sequestration impacts on global climate change and food security. Science 304, 5677: 1623-1627. DOI: 10.1126/science.1097396

Liagre F, Pisanelli A, Moreno G, Bellido M, Mayus M, Postma M, Schindle B, Graves AR, Mantzanas K, Dupraz C (2005) Deliverable 2.3. Survey of farmers' reaction to modern silvoarable systems in Europe: will European farmers adopt silvoarable agroforestry technology in the near future? Report prepared for the SAFE project.

Lorenz K, Lal R (2014) Biochar application to soil for climate change mitigation by soil organic carbon sequestration. Plant Nutri Soil Sci 177, 5: 651-670. DOI: 10.1002/jpln.201400058

Martineau H, Wiltshire J, Webb J, Hart K, Keenleyside C, Baldock D, Bell H, Watterson J (2016) Effective performance of tools for climate action policy - meta-review of Common Agricultural Policy (CAP) mainstreaming. Ricardo-AEA \& IEEP, Didcot, UK.

Mayus M, Van Keulen H, Stroosnijder L (1999) A model of tree-crop competition for windbreak systems in the Sahel: description and evaluation. Agrofo Syst 43, 3: 183-201. DOI: 10.1007/978-94-017-0679-7_12

Mbow C, Smith P, Skole D, Duguma L, Bustamante M (2014) Achieving mitigation and adaptation to climate change through sustainable agroforestry practices in Africa. Curr Opin Environ Sustainability 6: 8-14. DOI: 10.1016/i.cosust.2013.09.002

Méndez VE, Bacon CM, Olson M, Morris KS, Shattuck A (2010) Agrobiodiversity and shade coffee smallholder livelihoods: A review and synthesis of ten years of research in Central America. Prof Geogr 62: 357-376. DOI: 10.1080/00330124.2010.483638

Mosquera-Losada MR, Freese D, Rigueiro-Rodríguez A (2008) Carbon sequestration in European agroforestry systems. In: Kumar BM, Nair PKR (eds). Carbon sequestration potential of agroforestry systems: opportunities and challenges. Adv Agrofor 8: 43-5. DOI: 10.1007/97894-007-1630-8

Mosquera-Losada MR, Santiago-Freijanes J, Pisanelli A, Rois M, Smith J, den Herder M, MorenoMarcos G, Malignier N, Mirazo JR, Lamersdorf N, Ferreiro-Domínguez N, Balaguer F, Pantera A, Rigueiro-Rodríguez A, Gonzalez P, Lorenzo JL, Romero R, Chalmin A, García de Jalón S, Burgess $P$ (2016). Extent and Success of Current Policy Measures to Promote Agroforestry across Europe. Deliverable 8.23 for EU FP7 Research Project AGFORWARD 613520 
Plieninger T, Kohsaka R, Bieling C, Hashimoto S, Kamiyama C, Kizos T, Penker M, Kieninger P, Shaw BJ, Sioen GB, Yoshida Y, Saito O (2017) Fostering biocultural diversity in landscapes through place-based food networks: a "solution scan" of European and Japanese models. Sustain Sci. DOI: 10.1007/s11625-017-0455-z

Pullin AS, Sutherland W, Gardner T, Kapos V, Fa JE (2013) Conservation priorities: identifying need, taking action and evaluating success. Key Top Conserv Biol 2:3-22

Ramachandran Nair PK, Mohan Kumar B, Nair VD (2009) Agroforestry as a strategy for carbon sequestration. Plant Nutri Soil Sci 172, 1: 10-23. DOI: 10.1002/jpln.200800030

Raymond CM, Frantzeskaki N, Kabisch N, Berry P, Breil M, Nita MR, Geneletti D Calfapietra C (2017) A framework for assessing and implementing the co-benefits of nature-based solutions in urban areas. Envir Sci Pol 77: 15-24. DOI: 10.1016/i.envsci.2017.07.008

Rehfeldt GE, Tchebakova NM, Parfenova YI, Wykoff WR, Kuzmina NA, Milyutin LI (2002) Intraspecific responses to climate in Pinus sylvestris. Glob Chang Biol 8, 9: 912-929. DOI: 10.1046/j.13652486.2002.00516.x

Rivest D, Lorente M, Olivier A and Messier C (2013) Soil biochemical properties and microbial resilience in agroforestry systems: Effects on wheat growth under controlled drought and flooding conditions. Sci Total Environ 463-464: 51-60. DOI: 10.1016/j.scitotenv.2013.05.071

Schoeneberger M, Bentrup G, de Gooijer H, Soolanayakanahally R, Sauer T, Brandle J, Zhou X, Current D (2012) Branching out: agroforestry as a climate change mitigation and adaptation tool for agriculture. J Soil Water Conserv 67:128-136. DOI:10.2489/jswc.67.5.128A

Sharrow SH, Ismail S (2004) Carbon and nitrogen storage in agroforests, tree plantations, and pastures in western Oregon, USA. Agrofor Syst 60: 123-130. DOI:

10.1023/B:AGFO.0000013267.87896.41

Sutherland WJ, Gardner T, Bogich TL, Bradbury RB, Clothier B, Jonsson M, Kapos V, Lane SN, Moller I, Schroeder M, Spalding M, Spencer T, White PCL, and Dicks LV (2014) Solution scanning as a key policy tool: identifying management interventions to help maintain and enhance regulating ecosystem services. Ecol Soc 19:3. DOI: 10.5751/Es-06082-190203

Syampungani S, Chirwa PW, Akinnifesi FK, Ajayi OC (2010) The potential of using agroforestry as a win-win solution to climate change mitigation and adaptation and meeting food security challenges in Southern Africa. Agric J 5, 2: 80-88. ISSN : 1816-9155

Torralba M, Fagerholm N, Burgess PJ, Moreno G, Plieninger T (2016). Do European agroforestry systems enhance biodiversity and ecosystem services? A meta-analysis. Agric Ecosyst Environ 230: 150-161. DOI: 10.1016/j.agee.2016.06.002

Tsonkova P, Quinkenstein A, Böhm C, Freese D, Schaller E (2014) Ecosystem services assessment tool for agroforestry (ESAT-A): An approach to assess selected ecosystem services provided by alley cropping systems. Ecol Ind 45: 285-299. DOI: 10.1016/j.ecolind.2014.04.024

Upson MA (2014) The carbon storage benefits of agroforestry and farm woodlands. PhD Thesis. Cranfield University. Available at: http://dspace.lib.cranfield.ac.uk/handle/1826/9298

Upson MA, Burgess PJ, Morison JIL (2016) Soil carbon changes after establishing woodland and agroforestry trees in a grazed pasture. Geoderma 283: 10-20. DOI: 10.1016/i.geoderma.2016.07.002

Verchot LV, Noordwijk MV, Kandji S, Tomich T, Ong C, Albrecht A, Mackensen J, Bantilan C, Anupama KV, Palm C (2007) Climate change: linking adaptation and mitigation through agroforestry. Mitig Adapt Strateg Glob Change 12: 901-918. DOI: 10.1007/s11027-007-9105-6 